\title{
Työelämän kvalifikaatiovaatimusten ulottuvuudet 1990-luvulla
}

\author{
Sekä Suomessa että ulkomailla kvalifikaatiovaatimusten kehä on umpeu- \\ tumassa, koska nykyisin edellytetään työntekijöiltä samanaikaisesti \\ yleissivistäviä, ammatillisia ja sosiaalisia kvalifikaatioita. \\ 1990-luvun työmarkkinakansalaisen meriitiksi muodostuu laaja-alainen \\ opiskelu- ja työhistoria. Työuralla eteneminen aletaan vähitellen mieltää \\ etenemisvalmiutena työtehtävästä toiseen - ei enää välttämättä työpai- \\ kan alemmalta hierarkiatasolta ylemmälle.
}

Pohjoismaisissa hyvinvointivaltioissa useimmat sosiaaliset sopimukset on taattu valtiollisesti. Suomessa ovat vallinneet ainakin 1960-luvulta 1990-luvulle asti teollisen yhteiskunnan ja taloudellisen nousun mukaiset sosiaaliset sopimukset, jotka voidaan nimetä normaalityösuhdemalliksi, yhden ammatin hankkimisen malliksi, omistusasuntomalliksi, ydinperhemalliksi. (Suikkanen 1996). 1990-luvulla vakiintuneen ennätysmäisen työttömyyden ja talouskriisin oloissa nuo sosiaaliset sopimukset ovat kautta linjan kriisiytyneet.

Työssäkäyntimahdollisuudet ilmentävät elinkeinoelämässä ja työmarkkinoilla tapahtuneita rakennemuutoksia. 1980-luvulla pitkäaikaisten ja pysyvien työsuhteiden rinnalle tulivat lisääntyvässä määrin määräaikaiset työsuhteet. Osalla työvoimasta työmarkkina-asemaa alkoi kuvata parhaimmin väliaikainen tilapäisyys, jossa työssäkäynti- ja työttömyysjaksot vuorottelivat ennen pysyvään työsuhteeseen siirtymistä (Koistinen \& Suikkanen 1990). Väliaikainen tilapäisyys oli 1980-luvun noususuhdanteessa usein vapaaehtoista työntekijöiden pyrkiessä maksimoimaan työmarkkinoilla toimimisensa hyötyjä. 1990-luvulla osalla työvoimasta työmarkkina-asemaa on alkanut kuvata pysyvä tilapäisyys ja määräaikaistuvat työsuhteet. Pysyvää työmarkkinallista tilapäisyyttä luonnehtii työttömyysjaksojen, työssäkäynnin ja 1980-lukuun verrattuna usein myös opiskelun vuorottelu (Koistinen 1994). 1990-luvulla työmarkkina-asemien vuorottelu on yhä useammin työntekijöiden näkökulmasta vastentahtoista, koska työnantajat ovat alkaneet suosia sekä yksityisellä että julkisella sektorilla määräaikaisia työsuhteita. Uudentyyppiset työssäkäynnin muodot uudelleenrakenteistavat kvalifikaatiovaatimuksia ja niiden reaaliaikaistamisen mahdollisuuksia työnantajien, työntekijöiden sekä (aikuis)koulutusta järjestävien organisaatioiden näkökulmasta.

Työelämässä tarvittavat kvalifikaatiovaatimukset laajentuvat 1990-luvulla. Pelkkä työpaikka- ja tehtäväkohtainen ammatillinen osaaminen ei riitä samalla tavalla kuin aikaisemmilla vuosikymmenillä. Monitaitoisuuden vaatimukset lisääntyvät kaikissa ammattiryhmissä työsuhteiden luonteen ja työn sisällöissä tapahtuvien muutosten vuoksi. Samanaikaisesti tarvitaan sekä ammatillista perusosaamista että monitaitoisuuden "ammattivapaita" sisältöjä, joita ovat lähialojen perusosaaminen, yrittäjyystaidot, kansainvälisyystaidot, ATK-taidot, sosiaaliset yhteistyötaidot, olemassa olevan informaation rationaaliset hyödyntämistaidot ja jatkuvan opiskelun perusvalmiudet.

Työn sisällölliset muutokset ja sen myötä uudentyyppiset kvalifikaatiovaatimukset liittyvät perinteisen palkkatyössäkäynnin laadulliseen ja rakenteelliseen uudelleenmuotoutumiseen. 1990-luvun työmarkkinoilla työpaikoilla hierarkkisesta asemasta riippumatta työtehtävät edellyttävät jatkuvaa uusien asioiden ja taitojen omaksumishalua ja -valmiutta. Opiskelu ja monitaitoisuus muodostuvat yhdeksi keskeiseksi työmarkkinoilla pärjäämistä ohjaavaksi tekijäksi. Opiskelun ja tutkintojen arvo määräytyy sen mukaan, niissä määrin ne 
kykenevät vastaamaan työpaikkakohtaistuviin kvalifikaatiovaatimuksiin (Suikkanen \& Viinamäki 1993; Kasvio 1994; Väärälä 1994).

Sekä Suomessa että ulkomailla kvalifikaatiovaatimusten kehä on umpeutumassa, koska nykyisin edellytetään työntekijöiltä samanaikaisesti yleissivistäviä, ammatillisia ja sosiaalisia kvalifikaatioita. Yleissivistävät taidot ovat perusta ammatillisille opinnoille ja uusien asioiden oppimiselle. Ammatillisten taitojen avulla suoriudutaan varsinaisista työtehtävistä. Sosiaaliset eli elämänhallinta- ja ihmissuhdetaidot ovat tärkeitä, koska työtehtävien yksilösuoritukset muotoutuvat enenevässä määrin pari- tai ryhmäsuorituksiksi. Sosiaaliset taidot ovat tärkeitä myös sen vuoksi, että niiden avulla yksilöt voivat toimia paremmin työmarkkinoilla tapahtuvissa muutostilanteissa ja sopeutua uusiin työelämän vaatimuksiin (Suikkanen \& Viinamäki 1993.). Tällaiset kvalifikaatiovaatimusten uudet ulottuvuudet heijastuvat myös työmarkkinakansalaisuuteen.

Työmarkkinakansalaisuuden muotoutumisessa ovat keskenään vuorovaikutuksessa rakenteelliset ja yksilölliset tekijät (Marshall 1950; Barbalet 1988). Työmarkkinakansalaisuuden muotoutumisessa yksilötasolla ovat keskenään vuorovaikutuksessa opiskelu- ja työhistorian lisäksi yksilön reaaliaikainen työmarkkina-asema sekä työsuhdetyyppi. Muotoutumisen vaikuttavat niin ikään ammatilliset, yleissivistävät ja sosiaaliset kvalifikaatiot, perhepiiri mahdollisuuksineen ja rajoituksineen sekä opiskelu- ja työssäkäyntimahdollisuudet. Työmarkkinakansalaisuuden rakenteellisina realisoitumisen konteksteina toimivat institutionaaliset toimintakäytännöt (ml. hyvinvointivaltion palvelujärjestelmä, koulutus- ja työmarkkinat) lainsäädännöllisine mahdollisuuksineen ja rajoituksineen.

Työmarkkinakansalaisuutta rakenteistavat institutionaalisella tasolla työsuhteissa ja opiskelumahdollisuuksissa sekä hyvinvointivaltion palvelurakenteissa tapahtuvat muutokset. Yksilön tasolla työmarkkinakansalaisuutta rakenteistavat perhekäsitteen ideologisen ja toiminnallisen sisällön muutokset sekä koulutus- ja työmarkkinoiden uudenlainen suhde. Työmarkkinakansalaisuus on muotoutumassa aikaisempaa moniulotteisemmaksi ja yksilöllisemmäksi ilmiökokonaisuudeksi uudentyyppisten opiskelu- ja työssäkäyntireittien yleistymisen sekä toimeentuloperustan laajenemisen myötä.

Palkkatyössäkäyntiin perustuvassa yhteiskunnassa työmarkkinakansalaisuus on määrittänyt varsin suvereenisti toiminta- ja pärjäämismahdollisuuksia elämässä yleensä, koulutus- ja työmarkkinoilla sekä hyvinvointivaltion palvelujärjestelmän hyödyntämismahdollisuuksia 1990-luvun lamaan saakka. Palkkatyössäkäynti on ollut yleinen yhteiskunnallinen normaliteetti ja työllisen työvoiman ulkopuolella oleminen poikkeus työikäisten keskuudessa. Esimerkiksi hyvinvointivaltion palvelujärjestelmä on luotu pääsääntöisesti ansiosidonnaisuuden varaan. Kuitenkin 1990-luvun massiivinen työttömyys on alkanut vähitellen kyseenalaistaa tällaista työmarkkinakansalaisuuden hegemoniaa.

\section{Modernin työmarkkinakansalaisen elämänkulku}

Elämänkulun katkokset, nopeat siirtymät ja vaihtuvat tilanteet ovat yleistyneet. Perinteisen työmarkkinakansalaisen elämänkulun kronologinen vaihemalli on käsitteellisesti korvautumassa elämänkulun limittäisellä mallilla. 1990-luvulla kyseenalaistuvat yksilöiden perinteiset toimintamahdollisuudet koulutus- ja työmarkkinoilla sekä nykymuotoiset koulutus-, sosiaali- ja työvoimapoliittiset tukijärjestelmät. Enää ei välttämättä siirrytä suoraan nuoruuden koulutusputkesta keski-iän vakaaseen ja nousevaan uraputkeen ja lopulta eläkkeelle vanhuudenpäivien viettoon. Työpaikan menettämisestä, ammatillisten kvalifikaatioiden vanhentumisesta tai riittämättömyydestä aiheutuvat riskitilanteet yleistyvät jatkuvasti.

Työmarkkinakansalaisuutta rakenteistaa 1990-luvulla ensinnäkin se, kuuluuko työmarkkinakansalainen työlliseen vai työttömään työvoimaan, toiseksi se, työllistyykö hän avoimille vai tuetuille työmarkkinoille ja kolmanneksi se, työllistyykö hän määräaikaisiin vai pysyviin työsuhteisiin. Työmarkkina-aseman kautta 
määräytyvät työmarkkinoilla toimivien yksilöiden sosioekonomiset toiminta- ja pärjäämismahdollisuudet (vrt. Barbalet 1988, 15 - 17). Työmarkkinallinen elämänkulku on saamassa uusia ulottuvuuksia opiskelemisen, palkkatyössäkäynnin ja toimeentulon muodostumisen osalta.

Tärkeimmät muutokset liittyvät toisaalta opiskelun luonteen muuttumiseen kohti elinikäistä jatkuvaa opiskelua ja toisaalta palkkatyössäkäynnin taloudellisen merkityksen muuttumiseen entistä osittaisemmaksi toimeentulon perustaksi normaalin palkkatyön muodostuessa projektikohtaiseksi työssäkäynniksi. Työmarkkinoilla toimiva yksilö ei voi enää suunnitella samalla tavalla työmarkkinallista elämänkulkuaan tukeutuen yhteiskunnan instituutioihin ja niiden tarkoituksiin kuten ennen. Näyttää siltä, että vakavassa pysyvän alityöllisyyden tilanteessa yksilöiden ratkaisut elämänsä osalta murtavat vallitsevia instituutioita. Siitä seuraa, että yhteiskunnallisten toimenpiteiden seuraukset tulevat yhä arvaamattomimmiksi.

1990-luvun työmarkkinakansalaisen elämänkulun limittäistä mallia kuvaa integroitunut työhön sosiaalistumisen malli, jossa opiskelu, työssäkäynti ja vapaa-aika kietoutuvat toisiinsa (ks. Mahler 1989). Sekä yksityiset että julkiset elämisen areenat täydentävät toisiaan. Erilaisten kompromissien ja yksilöllisten elämisen ratkaisujen tekeminen kuvaavat työmarkkinakansalaisen elämänhallinnallisia kvalifikaatioita sekä luontevan integroituneen työhön sosiaalistumisen toteuttamismahdollisuuksia ja rajoituksia.

Työmarkkinakansalaisuuden limittäisiksi pääulottuvuuksiksi ovat muodostumassa palkkatyössäkäynti, sosiaalipoliittiset tulonsiirrot ja ns. kolmas sektori, joka on eräänlainen palkkatyössäkäynnin ja tulonsiirtojen yhdistelmä. Kolmas sektori tulee muodostamaan uudentyyppisen vaihtoehdon yhteiskunnallisten tukijärjestelmien osalta perinteiselle aikaisemmin passiivisuutta suosineelle työllisen työvoiman ulkopuolella olemiselle. Työllisen työvoiman ulkopuolella olevien henkilöiden on osallistuttava yleishyödylliseen yhteiskunnalliseen toimintaan ja/tai hankittava itselleen elämässä yleensä ja erityisesti työelämässä tarvittavia kvalifikaatioita saadakseen sosiaalipoliittisia tulonsiirtoja ilman, että heidän toimeentulonsa vaarantuu työmarkkinallisissa riskitilanteissa. Työmarkkinakansalaisuuden pääulottuvuuksia täydentävät aikuisiän sosialisaatio ja sukupolvien väliset uudentyyppiset toimeentulojärjestelyt.

Aikuisiän sosialisaatioon kuuluu jatkuva yleissivistävien, ammatillisten ja sosiaalisten kvalifikaatioiden reaaliaikaistaminen sekä työmarkkinoilla että yksityisessä elämässä pärjäämistä varten. 1990-luvulla eri ikäiset työmarkkinakansalaiset voivat ja/tai joutuvat tekemään samoja asioita elämän eri alueilla kuten perhe-elämässä uusperheiden yleistyessä, koulutusmarkkinoilla jatkuvan opiskelun yleistyessä ja työmarkkinoilla ei-tyypillisten työsuhteiden yleistyessä (Hoikkala 1993, 251; Väärälä 1994, 33 - 35). Opiskelu- ja työssäkäyntimahdollisuuksien rakenteistuessa uudelleen työmarkkinakansalaisten koulutus- ja työmarkkinaratkaisut heterogeenistuvat yksilöllisten työmarkkinasuunnitelmien myötä. Tällaisessa tilanteessa työmarkkinakansalaisten toimeentulo perustuu useisiin samanaikaisiin sekä perhepiirikohtaisiin yksityisiin että hyvinvointivaltiollisiin julkisiin toimeentulolähteisiin.

Työmarkkinoilla toimintaedellytysten luonteen muuttuminen kohti erityyppisiä ei-tyypillisiä työsuhdemuotoja ja jatkuvaa opiskelua merkitsee työmarkkinakansalaisten toimeentuloperustan pysyvää muuttumista, jossa palkkatulo ei ole kaikissa tilanteissa tärkein ja ensisijaisin toimeentulon muoto. Yhteiskunnallisesti tuetuista tulonsiirroista on tullut useimmille työmarkkinakansalaisille jatkuva osa toimeentuloa. Osalle työmarkkinakansalaisista hyvinvointivaltiollisista tukityöllistämistoimenpiteistä muodostuu normaali työssäkäynnin malli. Lineaarisen elämänkulun mallin murtuessa työmarkkinakansalaisten integroitunut työhön sosiaalistuminen lisääntyy ja eriytyy sekä määrällisesti että laadullisesti. Osalle se on vapaaehtoista -osalle se on pakko.

1990-luvun työmarkkinakansalaisen meriitiksi muodostuu laaja-alainen opiskelu- ja työhistoria. Työuralla eteneminen aletaan vähitellen mieltää etenemisvalmiutena työtehtävästä toiseen -ei enää välttämättä työpaikan alemmalta hierakiatasolta ylemmälle hierarkiatasolle. Opiskelu, työssäkäynti ja osalla työvoimasta myös eripituiset työttömyysjaksot muodostavat yhtenäisen jatkumon yksilöiden työmarkkinallisessa elä- 
mänkulussa. Erityisesti opiskelun ja työssäkäynnin vuorottelusta läpi työmarkkinallisen elämänkulun muodostuu vallitseva työmarkkinanormi. Työstä saatava palkka on yksi osa yksilön toimeentulokokonaisuutta. Eläkkeelle siirtyminen yksilöllistyy ja eriytyy.

Työssäkäynnin, opiskelun ja vapaa-ajan väliset rajat murenevat. Kun integroitunut työhön sosiaalistuminen on perinteisesti kuvannut nuorten siirtymävaihetta koulutusmarkkinoilta työmarkkinoille, niin nyt se on alkanut vähitellen kuvata kaikenikäisten työmarkkinakansalaisten koulutus- ja työmarkkinallista toimintaa. Yleisen taloudellisen tilanteen kehitys sekä paikalliset ja/tai alueelliset opiskelu- ja työssäkäyntimahdollisuudet vaikuttavat työmarkkinakansalaisten omien preferenssien lisäksi integroituneeseen työhön sosiaalistumisen mahdollisuuksiin.

Integroituneesta työelämään sosiaalistumisen mallista on saatu jo viitteitä 1980-luvun puolivälissä tehdyissä suomalaisissa ja ulkomaisissa tutkimuksissa, joissa on problematisoitu työpaikan menettämistilanteita (esim. Perrucci ym. 1988; Forsberg 1989; Gonäs 1989; Koistinen \& Suikkanen 1990; Jolkkonen ym. 1992; Heikkilä ym. 1993) sekä tutkimuksissa, joissa on problematisoitu nuorten elämisen urien muotoutumista (Sinisalo 1986; Rönkä 1994). Integroitunut työelämään sosiaalistuminen saa erilaisia painotuksia elämäntilanteen ja elämänvaiheen mukaan. Työmarkkinoille siirtymässä olevien nuorten keskuudessa korostuu ammatillisten kvalifikaatioiden konkretisoiminen joko työssäkäynnin ja/tai vapaa-ajan kautta (Viinamäki 1996). Työmarkkinoilla toimivien keskuudessa korostuu siellä pärjääminen, jota täydentää opiskelu ja/tai sitä rikkovat työttömyysjaksot yms. työmarkkinalliset riskitilanteet (Suikkanen \& Kauppinen 1996). Työmarkkinoilta siirtymässä olevien keskuudessa ovat ajankohtaisia yhä useammin työssäkäynnin ja eläkkeelle siirtymisen yhdistämismahdollisuudet (Kangas \& Suikkanen 1996).

1990-luvulla integroituneen työelämään sosiaalistumisen osalta ollaan varsin paradoksaalisessa ja pluralisoivassa tilanteessa. Se lisääntyy pakosta niiden työmarkkinakansalaisten keskuudessa, joilla on vaikeuksia kiinnittyä työmarkkinoille, pärjätä työmarkkinoilla tai poistua työmarkkinoilta. Tällöin sitä luonnehtii erilaisten koulutus- ja työvoimapoliittisten tukitoimenpiteiden vuorottelu. Lama on lisännyt työttömyyttä ja työmarkkinakansalaisten koulutus- ja työvoimapoliittisten tukitoimenpiteiden ohjaamaa työmarkkinallista elämänkulkua koulutuksellisesti ja/tai työmarkkinallisesti huono-osaisten työmarkkinakansalaisten keskuudessa (Santamäki-Vuori \& Sauramo 1995, 26 - 27). EU:iin liittyminen on laajentanut ja helpottanut ainakin periaatteessa työmarkkinakansalaisten liikkumista myös kansainvälisillä koulutus- ja työmarkkinoilla. Jälkimmäisen tuomista mahdollisuuksista nauttivat koulutuksellisesti ja/tai työmarkkinallisesti hyväosaiset työmarkkinakansalaiset.

\section{Visioita 1990-luvun työmarkkinakansalaisuudesta}

1990-lukua luonnehtii integroitunut työhön sosiaalistuminen, jossa opiskelusta muodostuu jatkuva prosessi. Ei-tyypillisten työsuhteiden yleistyessä ja heterogeenistuessa työn ja ei-työnvälinen raja hämärtyy. Pitkälle viety työnjako on murtumassa, jolloin työ ja koulutus ovat alkaneet lähentyä uudelleen. Opiskelu on työtä ja työ on opiskelua. Perinteinen palkkatyön ja perhe-elämän ulottuvuus pluralisoituvat, jolloin perheen ja palkkatyön välille muodostuu uusi harmaa vyöhyke. Uudella harmaalla vyöhykkeellä raja yksityisen perhe-elämän ja julkisen opiskelu- ja työelämän välillä murtuu muuttuen enemmän tilannesidonnaiseksi (Mahler 1989; Nyyssölä 1994.).

Kun fragmentoituneessa työhön sosiaalistumisen mallissa ovat olleet tärkeimpänä ammatilliset kvalifikaatiot, joita ovat tukeneet yleissivistävät ja vähemmässä määrin sosiaaliset kvalifikaatiot, niin integroituneessa työhön sosiaalistumisen mallissa sosiaalisista kvalifikaatioista on muodostumassa eräänlaisia peruskvalifikaatioita, joita tukevat yleissivistävät sekä vähäisemmässä määrin työpaikkakohtaistuvien kvalifikaatiovaatimusten vuoksi ammatilliset kvalifikaatiot. 
Työmarkkinakansalaisuus ja yleistyvä "ikäneutraali" integroitunut työhön sosiaalistumisen malli edellyttävät uudentyyppisiä kvalifikaatioita ja resursseja. jo nyt ja erityisesti tulevaisuudessa edellytetään uudentyyppisiä elämänhallinnallisia, koulutuksellisia ja työmarkkinallisia kvalifikaatioita, oma-aloitteisuutta sekä aikaisempaa suurempaa omaa vastuuta elämisen tilanteista niin yksityisillä areenoilla (perhepiirissä) kuin julkisillakin areenoilla (koulutus- ja työmarkkinoilla) hyvinvointivaltiollisten tukitoimenpiteiden ja työssäkäyntimahdollisuuksien rakenteistuessa uudelleen.

Voimassa olevan sosiaalisen sopimuksen vuoksi koulutus- ja työmarkkinoiden ja hyvinvointivaltion suhde alkaa muodostua ongelmalliseksi nykyisestä poikkeavaa työmarkkinakansalaisten mallia elävien elämänkulun ohjaamisessa, koska hyvinvointivaltio on virittynyt muun kuin joukkotyöttömyyden, katkoksellisten työsuhteiden ja toiminnallisten siirtymien varaan. Sosiaalipoliittisena tavoitteena on ollut kompensoida normaalityösuhteeseen liittyviä riskitilanteita. Useiden siirtymien yhteiskunta edellyttää kuitenkin lähtökohdiltaan toisentyyppistä yhteiskuntapolitiikkaa. Yhteiskuntapolitiikka ei lisääntyvien kustannusten vuoksi voi enää perustua tapahtuneiden menetysten korvaamiseen, vaan sen tulee mahdollistaa yksilön siirtymiä työpaikasta, työtehtävästä ja toiminnasta toiseen. Nykyisessä tilanteessa pitäisi painottaa yksilöllisyyskehityksen ja yhteiskunnallisen eriytymiskehityksen ottamista yhteiskunnallisen politiikan lähtökohdaksi ja perustaksi. Yhteiskunnan eriytyminen mitä ilmeisemmin vain kiihtyy laajassa työvoiman alikysyntätilanteessa. Näissä oloissa vanhat käsitykset yksilön elämänkulusta asettuvat kokonaan uuteen valoon.

Laman myötä työssäkäyntimahdollisuuksien uudelleenrakenteistuessa sekä työmarkkinakansalaisten että institutionaalisten toimintakäytäntöjen (ml. hyvinvointipalveluorganisaatioiden ja työnantajien toimintaperiaatteet) näkökulmasta ratkaisevaksi tekijäksi muodostuvat työmarkkinoilla toimivien yksilöiden toimintaorientaatiot, strategiset valinnat ja valintamahdollisuudet koulutus- ja työmarkkinallisissa ratkaisutilanteissa. Tällöin on keskeistä se, miten työmarkkinakansalaisten yksilölliset preferenssit ja institutionaaliset toimintakäytännöt kohtaavat toisensa. Kykenevätkö esimerkiksi hyvinvointivaltion palveluorganisaatiot vastaamaan uudentyyppisiin työmarkkinakansalaisten tarpeisiin? Ohjaavatko hyvinvointivaltion tukitoimenpiteet työmarkkinakansalaisten koulutus- ja työmarkkinaorientaatioita? Muuttavatko työnantajien käyttämät rekrytointistrategiat työmarkkinakansalaisten toimintaorientaatiota koulutus- ja työmarkkinoilla? Ohjaavatko koulutus-, työvoimapoliittiset jne. tukitoimenpiteet työnantajien rekrytointistrategioita? Millaisia seurauksia on jatkuvasti yleistyvällä vastentahtoisella tilapäisyydellä työmarkkinakansalaisten (lähi)tulevaisuuden elämäntilanteisiin ja tulevaisuuden suunnitelmiin?

\section{LÄHTEET}

Barbalet, J. M. 1988. Citizenship. Rights, Struggle and Class Inequality. Bristol.

Forsberg, G. 1989. Industriomvandling ocb könstruktur. Fallstudier på fyra lokala arbetsmarknader Geografiska regionstudier Nr. 20. Kulturgeografiska institutionen vid Uppsala universitet Uppsala.

Gonäs, L. 1989. En fråga om kön. Kvinnor och män i strukturomvandlingens spår. Stockholm.

Heikkilä. I. \& Kivekäs, M. \& Suikkanen, A. \& Viinamäki, L. 1993. Kuinkas sitten kävikään... Lapin yliopiston yhteiskuntatieteellisiä julkaisuja C 14. Rovaniemi.

Hoikkala, T. 1993. Katoaako kasvatus, himmeneekö aikuisuus? Aikuistumisen puhe ja kulttuurimallit. Jyväskylä.

Jolkkonen, A. \& Koistinen, P. \& Kurvinen, A. \& Linnakangas, R. \& Suikkanen, A. 1992. LOPPUTILI JA SALDO. Tutkimus Postipankin maksupalvelutoiminnon keskittämisestä ja henkilöstön sopeutumisesta. Joensuun yliopisto. Karjalan tutkimuslaitoksen monisteita. N:o 9/1992. Joensuu.

Kangas, O. \& Suikkanen, A. 1996 Vuonna 1925 syntyneiden elämänkulku ja hyvinvointivaltiolliset järjestelyt. Käsikirjoitus. 
Koistinen, P. 1994. Jaetaan työtä - nostetaan tuottavuutta. Dialogi 4/1994

Koistinen, P. \& Suikkanen, A. 1990. Edessä pysyvä tilapäisyys. Tapaustutkimuksia joukkoirtisanomisista ja niistä suoriutumisesta. Joensuun yliopisto. Karjalan tutkimuslaitoksen monisteita. N:o 2/1990. Joensuu.

Mahler, F. 1989. Transition and Socialisation. Teoksessa Adamski, W. \& Grootings, P. (Eds.) Youth, Education and Work in Europe. New York.

Marshall, T. H. 1950. Citizenship and social class and other essays. Cambridge.

Nyyssölä, K. 1994. Nuoret ja työmarkkinoiden joustavuus. Nuorten joustava työllistyminen työvoima- ja koulutuspoliittisena ongelmana. Turun yliopisto. Koulutussosiologian tutkimuskeskus. Raportteja 20. Turku.

Perrucci, C. C. \& Perrucci, R. \& Targ, D. B. \& Targ, H. R. 1988. Plant Closings. International Context and Social Costs. New York.

Rönkä, A. 1994. Nuoren aikuisen sosiaalinen selviytyminen. Teoksessa Heikkilä, M. \& Vähätalo, K. (Toim.) Huono-osaisuus ja hyvinvointivaltion muutos. Tampere.

Santamäki-Vuori, T. \& Sauramo, P. 1995. Nuorten työttömyys Suomessa vuosina 1993 - 94. Työpoliittinen tutkimus Nro 107. Työministeriö. Helsinki.

Sinisalo, P. 1986. Työvoimaura ja yksilön kehitys. Työvoimapoliittisia tutkimuksia Nro 63. Työministeriö. Helsinki.

Suikkanen, A. 1996. Palkkatyön murroksen vaikutus suomalaisten elämänuraan. Teoksessa Katja, O. (toim.) Avaimia avoimeen korkeakouluun. Nuorisokoulun tehtävä ja oppilaitosten yhteistyö. Juva.

Suikkanen, A. \& Kauppinen, P. 1996. Suomalaisten hyvinvointimuutokset selviytymisen ja syrjäytymisen pelinä. Käsikirjoitus.

Suikkanen, A. \& Viinamäki, L. 1993. Jatkuvan opiskelun välttämättömyys? Tutkimus aikuisena opiskelun tilanteista epävakaistuvilla työmarkkinoilla. Työpoliittinen tutkimus Nro 42. Työministeriö. Helsinki.

Viinamäki, L. 1996. Opiskelemaan, työhön, työttömäksi? Tutkimus nuorten itsenäistymisen ehdoista 1990-luvulla. Lapin yliopiston yhteiskuntatieteellisiä julkaisuja B 23. Rovaniemi.

Väärälä, R. 1994. Ammattikoulutus ja kvalikaatiot. Acta Universitatis Lapponiensis 9. Rovaniemi. 